\title{
A strange case of severe but fleeting hypoxemia in patient with COVID-19 infection: maybe virus-induced pulmonary Raynaud's phenomenon?
}

\author{
Nicola Barbarito \\ Don Gnocchi Foundation, Palazzolo Institute, Pneumology, Milan, Italy
}

\begin{abstract}
This case-report describes severe acute respiratory failure in a patient with a COVID-19 positive nasopharyngeal swab that spontaneously resolved within a few hours. It is speculated that the virus may have caused a fleeting pulmonary vasospasm.
\end{abstract}

\section{Introduction}

In Autumn 2020, the Coronavirus disease 19 (COVID-19) severely hit the Northern Italy, retracing similar epidemiological data to February and March 2020, when in Lombardy, over only 4 weeks, approximately $35 \%$ of 7285 patients admitted in hospital experienced acute respiratory failure (ARF) requiring any form of respiratory support [1].

A markedly increased mortality was noted in a subgroup of

Correspondence: Nicola Barbarito, Fondazione Don Gnocchi, Istituto Palazzolo, Pneumologia, via Don Luigi Palazzolo 21, 20149 Milano, Italy.

Tel. +39.02.39703383

E-mail: nicola.barbarito@yahoo.it

Ethics approval and consent to participate: No ethical committee approval was required for this case report by the Department, because this article does not contain any studies with human participants or animals. Informed consent was obtained from the patient included in this study.

Availability of data and materials: All data underlying the findings are fully available.

Conflict of interest: The author declares no conflict of interest.

Key words: SARS-CoV-2; COVID-19; respiratory failure: pathogenesis.

Received for publication: 28 November 2020.

Accepted for publication: 8 January 2021.

${ }^{\circ}$ Copyright: the Author(s), 2021

Licensee PAGEPress, Italy

Monaldi Archives for Chest Disease 2021; 91:1706

doi: 10.4081/monaldi.2021.1706

This article is distributed under the terms of the Creative Commons Attribution Noncommercial License (by-nc 4.0) which permits any noncommercial use, distribution, and reproduction in any medium, provided the original author(s) and source are credited. patients who had COVID19-related acute respiratory distress syndrome (ARDS) characterized by low static compliance of the respiratory system and high D-dimer concentration. Furthermore, the dead-space was found higher in patients with COVID19-related ARDS with very high D-dimer levels [2]. Computed tomography (CT) angiogram studies showed more prominent filling defects or occlusion of the pulmonary vasculature in patients with COVID19-related ARDS and high D-dimer concentration, similarly to patients with H1N1-associated ARDS [3].

\section{Case Report}

A 91-year-old female, with a medical history of hypertension, were admitted in our rehabilitation department in Milan (Lombardy) on September $28^{\text {th }}, 2020$ to treat the outcomes (hemiparesis, aphasia and dysphagia) of a right ischemic stroke.

After a period of progressive improvement in neurological symptoms, cough appeared and nasopharyngeal swab (NPS) resulted positive for severe acute respiratory syndrome coronavirus 2 (SARS-CoV-2) RNA. Cough resolved completely in about a week, with no other symptoms of COVID-19, with normal both blood test and vital signs (including oxygen saturation as measured by pulse-oximetry, $\mathrm{SpO}_{2}$, which ranged from $94 \%$ to $96 \%$ on room air).

On November $23^{\text {rd }}$ her control NPS was still positive for SARS-CoV-2 RNA. The next morning, at 8 am, all vital signs were still normal, including $\mathrm{SpO}_{2}$ which was $95 \%$ on room air. However, at a check made at 11 am, the $\mathrm{SpO}_{2}$ was $84 \%$ on room air, although the patient continued to be completely asymptomatic, with normal respiratory frequency $(14 \mathrm{bpm})$ and any other vital parameter (temperature of $36.5^{\circ} \mathrm{C}$, blood pressure of $140 / 80$ $\mathrm{mmHg}$, heart rate of $76 \mathrm{bpm}$ ). The patient's lungs were clear to auscultation bilaterally and no accessory muscle use or abdominal paradox were appreciable. Hemogasanalysis on room air showed a severe impairment in intra-pulmonary gas exchanges, with $\mathrm{PaO}_{2} / \mathrm{FiO}_{2}=224$ and $\mathrm{PA}-\mathrm{aO}_{2}=62.7 \mathrm{mmHg}: \mathrm{PaO}_{2}=47$ $\mathrm{mmHg}, \mathrm{PaCO}_{2}=32 \mathrm{mmHg}, \mathrm{pH}=7.46, \mathrm{HCO}_{3}$-std $=24 \mathrm{mmol} / \mathrm{L}$, BEecf $=-1 \mathrm{mmol} / \mathrm{L}$. Chest X-ray showed no opacities or other abnormality (Figure 1). Supplemental oxygen therapy required $15 \mathrm{l} / \mathrm{min}$ on a non-rebreathing mask to obtain stable $\mathrm{SpO}_{2} 90 \%$ (settling on 92-94\%), since with the Venturi mask at highest $\mathrm{FiO}_{2}$ of $0.6 \mathrm{SpO}_{2}$ was $88-90 \%$. The patient underwent blood tests, low-molecular-weight heparin was administered subcutaneously (enoxaparin $6000 \mathrm{UI}, 100 \mathrm{UI} / \mathrm{Kg}$ ), and she was subsequently sent for a CT angiography of the chest. CT scan showed nor pulmonary embolism nor parenchymal abnormality, except for a 6.6 $\mathrm{mm}$ nodule on the left. Transthoracic echocardiogram assessment resulted normal, in particular it did not showed right ven- 
tricular dilatation or dysfunction, or elevated pulmonary arterial systolic pressure. Lab work was notable only for an elevated Ddimer at $421 \mathrm{ng} / \mathrm{ml}$ and a probrain natriuretic peptide (BNP) of $130 \mathrm{pg} / \mathrm{ml}$ (any other measure was normal, including blood cell count of $9140 / \mathrm{mcl}$, absolute lymphocyte count of $3260 / \mathrm{mcl}$, and C-reactive protein of $0.27 \mathrm{mcg} / \mathrm{dl}$ ).

Surprisingly, at a check made at $3 \mathrm{pm}$, the $\mathrm{SpO}_{2}$ was $99 \%$ with 151 of supplemental $\mathrm{O}_{2}$ via reservoir bag, and it was possible decrease the $\mathrm{FiO}_{2}$, until $\mathrm{SpO}_{2}$ of $94 \%$ was obtained with a flow of $21 /$ min via nasal cannulae.

The following morning it was possible to completely suspend oxygen-therapy, $\mathrm{SpO}_{2}$ resulting stable at $94 \%$ on room air, with hemogasanalysis on room air showing: $\mathrm{PaO}_{2}=63 \mathrm{mmHg}, \mathrm{PaCO}_{2}=$ $39 \mathrm{mmHg}, \mathrm{pH}=7.42, \mathrm{HCO}_{3}$-std $=25 \mathrm{mmol} / \mathrm{L}, \mathrm{BEecf}=0.8 \mathrm{mmol} / \mathrm{L}$ $\left(\mathrm{PaO}_{2} / \mathrm{FiO}_{2}=300\right.$ and $\left.\mathrm{PA}-\mathrm{aO}_{2}=38.0 \mathrm{mmHg}\right)$. At blood test control, D-dimer was $320 \mathrm{ng} / \mathrm{ml}$ and BNP was $125 \mathrm{pg} / \mathrm{ml}$ (any other measure was always normal). Timetable of the drastic and sudden changes in intra-pulmonary gas exchanges is reported in Table 1.

\section{Discussion}

It is very difficult, with the available data, to explain the reason for such a rapid spontaneous resolution of a severe ARF. Only speculative assumptions can be made.

It is could be think of a very dynamic phenomenon, such as a

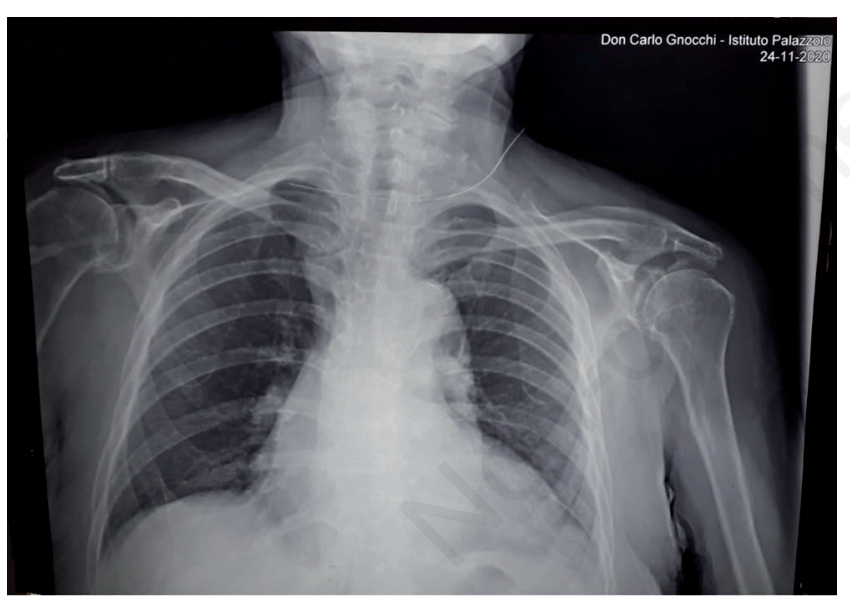

Figure 1. Chest X-ray showing no opacities or other abnormality. pulmonary vasospasm causing an increase in dead space ventilation with a redistribution of blood flow in the lung.

A recent study suggests that intravascular pathology plays a major role increasing dead space and causing hypoxemia in COVID-19-related ARDS. This role could explain the observation that static compliance and $\mathrm{PaO} 2 / \mathrm{FiO} 2$ were not correlated in COVID-19-related ARDS, but were correlated in classical ARDS [2]. Dead-space ventilation might be due to mechanisms other than microclots.

In patients with HIV infection, some authors believe that the development of pulmonary hypertension $(\mathrm{PH})$ is linked to an indirect mediated action of the HIV virus by inflammatory cytokines, growth factors [5] or endothelin-1 (ET-1) [6]. Moreover, a constitutional predisposition could play an important role since $\mathrm{PH}$ affects only a minority of patients with HIV infection [7].

The virus SARS-CoV-2 causes an endothelial dysfunction [8], and this could lead to reduced production of vasodilators agents, such as nitric oxide and prostacyclin, and an increased synthesis of vasoconstrictor factors, such as ET-1 [9]. It could also be hypothesized that the virus could alter plasma concentrations of vasoactive substances of non-endothelial derivation: an increase in plasma levels of substances with vasoconstrictive function such as serotonin [10] and a reduction in plasma levels of functional substances of vasodilation such as vasoactive intestinal polypeptide [11].

This could have therapeutic implications, such as using inhaled nitric oxide (iNO) in a subgroup of patients with COVID-19. iNO is widely used as a rescue therapy for severely hypoxemic patients with and without PH [12], believed to have a potential antiviral mechanism of action [13], remembered as an effective therapy during the severe acute respiratory syndrome outbreak in 2003 by improving oxygenation in patients with significant hypoxemia [14], and already used by several authors in patients with COVID19 [15].

\section{References}

1. Lombardy Region. Official Bulletin March 18th, 2020. Available from: https://www.open.online/2020/03/18/coronavirus-bollettino-regione-lombardia-18-marzo

2. Grasselli G, Tonetti T, Protti A, et al. Pathophysiology of COVID-19-associated acute respiratory distress syndrome: a multicentre prospective observational study. Lancet Respir Med 2020;8:1201-8.

3. Bunce PE, High SM, Nadjafi M, et al. Pandemic H1N1 influenza infection and vascular thrombosis. Clin Infect Dis 2011;52:e14-7.

Table 1. Timetable of the intra-pulmonary gas exchanges. ${ }^{*} 0.90=151 / \mathrm{min}$ via non-rebreathing mask, $0.28=21 / \mathrm{min} v i a$ nasal cannulae [4].

\begin{tabular}{|c|c|c|c|c|c|c|c|c|c|c|}
\hline Date & Hours & $\mathrm{FiO}_{2}$ & Sp02 (\%) & $\mathrm{PaO}_{2} / \mathrm{FiO}_{2}$ & $\begin{array}{c}\mathrm{PA}^{-a O_{2}} \\
(\mathrm{mmHg})\end{array}$ & $\begin{array}{c}\mathrm{PaO}_{2} \\
(\mathrm{mmHg})\end{array}$ & $\begin{array}{c}\mathrm{PaCO}_{2} \\
(\mathrm{mmHg})\end{array}$ & $\mathrm{pH}$ & $\begin{array}{l}\mathrm{HCO}_{3} \text {-std } \\
(\mathrm{mmol} / \mathrm{L})\end{array}$ & $\begin{array}{c}\text { BEecf } \\
(\mathrm{mmol} / \mathrm{L})\end{array}$ \\
\hline $24 / 12$ & 8:00 a.m. & 0.21 & 95 & & & & & & & \\
\hline $24 / 12$ & 11:00 a.m. & 0.21 & 84 & 224 & 62.7 & 47 & 32 & 7.46 & 24 & -1 \\
\hline $24 / 12$ & 11:20 a.m. & 0.60 & 89 & & & & & & & \\
\hline $24 / 12$ & 11:40 a.m. & $0.90 *$ & 93 & & & & & & & \\
\hline $24 / 12$ & 3:00 p.m. & $0.90 *$ & 99 & & & & & & & \\
\hline $24 / 12$ & 3:30 p.m. & $0.28 *$ & 94 & & & & & & & \\
\hline $25 / 12$ & 8:00 a.m. & 0.21 & 94 & 300 & 38.0 & 63 & 39 & 7.42 & 25 & 0.8 \\
\hline
\end{tabular}


4. O'Driscoll BR, Howard LS, Earis J, et al. BTS guideline for oxygen use in adults in healthcare and emergency settings. Thorax 2017;72:i1-i90.

5. Humbert M, Monti G, Fartoukh M, et al. Platelet-derived growth factor expression in primary pulmonary hypertension: comparison of HIV seropositive and HIV seronegative patients. Eur Respir J 1998;11:554-9.

6. Ehrenreich H, Rieckmann P, Sinowatz F, et al. Potent stimulation of monocytic endothelin-1 production by HIV-1 glycoprotein 120. J Immunol 1993;150:4601-9.

7. Palazzini M, Manes A, Negro L, et al. Pulmonary arterial hypertension. Part I: pathobiologic, pathophysiologic, clinical and diagnostic aspects. G Ital Cardiol 2009;10:271300.

8. Jung F, Krüger-Genge A, Franke RP, et al. COVID-19 and the endothelium. Clin Hemorheol Microcirc 2020;75:7-11.

9. Budhiraja R, Tuder RM, Hassoun PM. Endothelial dysfunction in pulmonary hypertension. Circulation 2004;109:159-65.

10. Hervé P, Launay JM, Scrobohaci ML, et al. Increased plasma serotonin in primary pulmonary hypertension. Am J Med 1995;99:249-54.

11. Petkov V, Mosgoeller W, Ziesche R, et al. Vasoactive intestinal peptide as a new drug for treatment of primary pulmonary hypertension. J Clin Invest 2003;111:1339-46.

12. Teman NR, Thomas J, Bryner BS, et al. Inhaled nitric oxide to improve oxygenation for safe critical care transport of adults with severe hypoxemia. Am J Crit Care 2015;24:110-7.

13. Akerström S, Gunalan V, Keng CT, et al. Dual effect of nitric oxide on SARS-CoV replication: viral RNA production and palmitoylation of the $\mathrm{S}$ protein are affected. Virology 2009;395:1-9.

14. Chen L, Liu P, Gao H, et al. Inhalation of nitric oxide in the treatment of severe acute respiratory syndrome: a rescue trial in Beijing. Clin Infect Dis 2004;39:1531-5.

15. Adusumilli NC, Zhang D, Friedman JM, Friedman AJ. Harnessing nitric oxide for preventing, limiting and treating the severe pulmonary consequences of COVID-19. Nitric Oxide 2020;103:4-8. 